\title{
Instilling Critical Pedagogy in the Italian Language Classroom
}

\author{
Giuseppe Formato \\ Lesley University, Cambridge, MA, USA
}

\begin{abstract}
This article explores theoretical underpinnings for the use of critical pedagogy in the Italian language learning classroom. Its description of various components of critical theory lends a historical context for critical pedagogy, particularly in the arguments of Gramsci and the Frankfurt School, that contrast with positivist tenets. These critical elements extend to the classroom in a Freirian framework, including concepts such as banking, coding, and conscientization. Such lenses apply to the realm of foreign language teaching, particularly aspects of transformative learning. Issues surrounding materials design are also considered. Avenues and opportunities for critical thinking are explored through lesson plan ideas, as well as possible thematic unit topic suggestions in Italian courses. This paper concludes with questions for future research by language scholars in the field of education, in addition to a call to action for educators of Italian.
\end{abstract}

Index Terms-positivism, critical theory, Frankfurt School, critical pedagogy, conscientization, banking, coding, language pedagogy, transformative learning, thematic units, Italian

\section{INTRODUCTION}

Many elements in the field of education share common instrumentalist and positivist orientations towards language and teaching. In this view, language becomes an objective system that theorists can more or less describe and practitioners can transmit, and teaching becomes a technical process prescribed by experts and implemented by teachers (Pennycook, 1990). These questions seem to derive on the one hand from researchers' attempts to understand the language-learning process according to the positivistic paradigms of the social sciences, and on the other hand from teachers' struggles to relate this knowledge to the daily realties of classroom practices. What is lacking is a view of the social, cultural, political, and historical context and implications of language teaching. The field of Italian language education presents a particularly far-reaching lacuna in this regard because there has been no such critical application to this area of pedagogy. This absence allows language to be reduced to a system for transmitting messages rather than an ideational, signifying system that plays a central role in how we understand ourselves and the world.

Looking at language as a political enterprise, critical pedagogy aims to raise learners' critical consciousness to be aware of their sociopolitical surroundings and to fight against the status quo, with the intent of transforming both the classroom and larger society (Norton \& Toohey, 2004). Although critical pedagogy was developed primarily in the 1970s, it entered the second-language (L2) arena in the late 1980s, when pragmatic attitudes and communicative approaches surrounded L2 teaching (Canagarajah, 2005). The intent of this article is partly to highlight the practical relevance of critical pedagogies to the Italian language classroom.

Additionally, while materials are usually considered the core resources in language-learning programs (Richards, 2010), remarkably little research has been conducted on materials development in critical pedagogy. The area is underdeveloped (Rashidi \& Safari, 2011), with a complete dearth of research regarding Italian language instruction. In the absence of a comprehensive framework to develop materials on critical pedagogy, this study is also intended to provide considerations for a materials-design and thematic framework wherein the main principles of critical pedagogy are included and applied. It seeks to design a teaching materials model with the purpose of leading educational situations to flourish students as transformation agents in society. Materials choice is imperative to develop critical thinking, acceptance of cultural multiplicity, and ideological mindfulness (Álvarez, Calvete \& Sarasa, 2012) rather than using language to reinforce stereotypes, prejudices, and lack of acceptance towards oneself and others (Araya Araya, 2007). Moreover, critical pedagogy-oriented materials challenge students' commonsense assumptions by uncovering power relations inherent in discourses of different cultural groups. With these purposes in mind, this article addresses the question, What principles of material and thematic development could be derived from the philosophies of critical pedagogy to teach Italian from a critical perspective? The stance taken is that critical thinking is relevant for Italian language-learning classrooms.

\section{CRitical Theory}

\section{A. Positivism, Gramsci, and the Frankfurt School}

Gramsci claimed that with the growth of modern science and technology, social control was exercised less through physical power than through dispersal of an intricate system of standards and necessities. The latter was used to advance 
to institutional authority a degree of unity and certainty and afford it apparent universality and legitimation. Gramsci called this form of control "ideological hegemony," a method of control that not only manipulated perception, but also drenched and established the everyday practices that formed performance (Gramsci, Hoare \& Nowell-Smith, 1971). Hence, ideological hegemony referred to those systems of practices, meanings, and values that gave validity to the dominant society's institutional arrangements and interests (Giroux, 1979). Gramsci's analysis is relevant to providing a theoretical foundation of social and cultural reproduction, particularly because it reproduces social processes distributed in learning spaces.

Views of education and curricula based on positivist interpretations of knowledge tend to make strong claims of objectivity and empirical verification of facts without questioning the nature of knowledge, truth, or the social, cultural, or political interests of different claims to knowledge (Pennycook, 1990). The major assumptions underlying the positivist culture are drawn from the logic and method of inquiry associated with the natural sciences (Dallmayr \& McCarthy, 1977). Based on the reason of scientific methodology, with its interest in description, calculation, and practical control, the principal of rationality in the natural sciences was viewed as superior to the speculative social sciences (Giroux, 1979).

Positivism associates knowledge with scientific practice. Questions regarding the social structure of knowledge and constitutive benefits behind the collection and organization of facts are hidden under the postulation that knowledge is objective and value-free. This view does not consider information from the subjective world of perception, philosophy, and nonscientific theoretical frameworks to be relevant (Giroux, 1979). In this light, values are not associated with facts. They are considered irrational and subjective emotional responses (Habermas, 2014). The idea that facts, theory, and inquiry can only be quantitatively determined and used is susceptible to conservative values. Unable to reflect on its own presuppositions or provide for critical reflection in general (Husserl \& Lauer, 1994), it ends up uncritically supportive of the status quo. In the positivist framework, rather than comprehending the world holistically as a network of interconnections, learners are taught to approach problems as if they existed in isolation, detached from the social and political forces that give them meaning. In turn, this creates a tunnel vision in which only a small segment of social reality is open to examination (Giroux, 1979). It also leaves unchallenged those economic, social, political, and social frameworks that attained their current forms naturally, as opposed to having been constructed by historically specific interests.

In response to the rise of fascism and Nazism and the failure of orthodox Marxism, the Frankfurt School approached ideas surrounding control and liberation from a different standpoint. It placed greater weight on the issue of how the domain of culture and everyday life embodied a new territory of control (Giroux, 1979). Similar to Nietzsche's warning concerning people's blind faith in reason, Adorno and Horkheimer critiqued modernity's steadfast faith in the promise of the Enlightenment's rationality to save the world from ignorance, fantasy, and misery (Nietzsche \& Collin, 2014). Adorno, Horkheimer, and Marcuse believed the progression of reasoning had infiltrated all facets of everyday life from mass media to education (Wellmer \& Cumming, 1974). According to Adorno (2007), the calamities of reason occur as society becomes more rationalized because it loses its critical capacity to realize social harmony, becoming then a tool of society and resulting in critiques considered illogical (Giroux, 1979). Positivism slurs nonpositive thinking as mere gossip. For the Frankfurt School, this mindset threatened the concept of subjectivity and critical thinking. Our society celebrates positivism, free from context and ethical commitments, as undisputed facts. Presented as neutral and scientific, knowledge then becomes rational based on whether it is efficient and economic. Those associated with the Frankfurt School called for dialectics in theory. They hoped to bring about critical thought and reveal insufficiencies and imperfections in what mainstream society considered a finished system of thought (Held, 2006). For these thinkers, rationalism was no longer just the exercise of critical thought, but a crossroads of action, liberation, and society (Giroux, 1979).

A more critical understanding of knowledge would describe it as a social construct associated with human intentionality and conduct. Interpreting this view into pedagogical principles, the concept of knowledge must link to the concept of power (Giroux, 1979). This means classroom knowledge can be used in the interest of either domination or liberation (Greene, 1989). It can be a critical tool to disrupt false logic or to unreflectively legitimize explicit interests appearing value-free and unsusceptible to criticism. However, in a condition of post-modernity, we are likely to value and recognize nonhomogeneity rather than assume some unitary progress (Gibson-Graham, 2006).

\section{B. Critical Pedagogy}

Approaching pedagogy with a critical lens begins with the central notion that knowledge is socially constructed. Critical pedagogy identifies that all knowledge is constructed in a particular social, cultural, and historical joining of relationships. All assertions to knowledge mirror the group's particular concerns and are tied up in power relationships (Pennycook, 1990). This argument opposes all claims that knowledge can be value-free, neutral, ahistorical, or general. Therefore, as an ideological process, it allows learners to view relationships between knowledge, culture, power, and ideology. Critical pedagogy seeks to investigate and make clear how knowledge is fashioned and legitimated within the classroom, in addition to challenging those forms of knowledge critically in an attempt to legitimize other subjugated forms and produce new ones (Giroux, 1988).

Critical pedagogy refers to teaching practices that report variances, power, or social stratification (Johnson \& Randolph, 2015). It is informed and produced by critical studies in other fields such as queer theory. Crookes (2012) 
posited that critical pedagogy is the most extensive form of social justice oriented in language teaching. It describes social justice approaches that use critical pedagogy to create social justice outcomes for learners, and is the route to arrive at social justice in the language classroom. Pedagogy reframes the field of language teaching, emphasizing a departure from traditional pedagogy that reinforces the meaning that students acquired from social conditioning in traditional education, whereas critical pedagogy tries to transform learners' meaning standpoints by resisting the main social purpose of education: to indoctrinate learners with social ideology (Kennedy, 1990). Social organizations use traditional pedagogy to prepare students to go about in the social conditions in which they find themselves while critical pedagogy prepares students to resist, reassess, reflect, and create change in response to social inequality.

An original voice of critical pedagogy, Paulo Freire (1970) used the term conscientization to describe the process of developing a critical awareness of one's social reality through reflection and action. This differs from his term, banking education, a process by which the instructor uncritically hands over knowledge as opposed to the knowledge being a focus of critical awareness. Learners of critical pedagogy instructors become aware of how ideology inhibits learning, obstructed by social habits and cultural forms that together form how they understand the world. These ideologies appear on the outside to be common sense and status quo (Norton \& Toohey, 2004), as opposed to structures intentionally skewed in favor of those in power. Because ideologies are difficult to perceive, uncritically transferred knowledge strengthens the existing hierarchies and structures. Education is thus never neutral (Shaull, 2007).

\section{Instructor and Students Roles}

Through the paradigm of critical pedagogy, teachers become problem posers (Aliakbari \& Faraji, 2011), a practice often absent in Italian language-learning classes. To understand this, Dewey (2017) — a pioneer of the progressivist movement of education in the United States whose central tenant held that traditional schooling does not serve a learner's needs or interests (Ooiwa-Yoshizawa, 2012)-believed learning through problem solving and practical application led learners to more active roles in determining their positions within society. Similarly, Kincheloe and McLaren (1998) posited that the instructor must empower leaners by raising their awareness of the process of reproducing an undemocratic status quo. Educators are thus transformative intellectuals with the knowledge and skills to alter existing disparities in society (Sadeghi, 2008). By creating appropriate social conditions, educators empower learners to become cultural producers who can revise their observations and sensitivities and understand how to question authoritarian powers (Giroux, 2008). Instructors can help develop critical consciousness that supports students to assess the legitimacy, justice, and authority within their educational and living circumstances. In this way, critical educators help learners recognize reasons behind the facts (Aliakbari \& Faraji, 2011). Learners and teachers should participate in questioning knowledge, but it is the instructor who helps students identify how to move forward critically in their training (Keesing-Styles, 2003). Students are dynamic participants. Together with the instructor, they learn to contest norms (Giroux, 2008). Critical learners are those who can reject or suspend judgement about a claim (Moore \& Parker, 2016). They should engage in social criticism to produce a public sphere in which people can exercise power over their own lives and learning (Giroux, 2008). By enabling learners to reflect on their own commonsense knowledge, they learn how to transform their lives, resulting in the Freirian shift to conscientization (Freire, 1970).

\section{CRitical Language Pedagogy}

Critical pedagogy offers many ways to move past Eurocentric tendencies within L2 teaching practices, techniques illuminating and relevant to diverse learners studying Italian in North America. Farias suggested this concept is built on a groundwork of understanding of how we function as humans and a conception of a common experience articulated by language - whatever that language or our relation to it might be. This raises awareness within the learner by considering language pedagogy as a social practice. Language does not exist outside its sociocultural milieu, particularly when operating within a set of pedagogical or institutional considerations. Critical language pedagogy could provide the concept of language itself as a critical practice involving self-consciousness and engagement with others when such awareness fosters a critical practice (Farias, 2005).

Critical pedagogy can also be utilized in the L2 classroom (Randolph \& Johnson, 2017), which functions all-too-often as a purely practical and proficiency-based class. Rather, the classroom becomes a place where educators take a more critical tactic towards teaching. Issues of immigration, inclusion, diversity, multiculturalism, and globalization dominate our country's present political environment. The study of languages enhances all of these. Integrating this type of pedagogy requires a critical deconstruction of dogmatic and established power structures, in addition to their unspoken and overt impacts in the curriculum development and organization. Critical pedagogy can be scrutinized at all levels of the world-language program.

\section{A. Importance of Culture}

Students must develop their intercultural communicative competence (Randolph \& Johnson, 2017), often a transformative learning process that deeply changes the way learners interrelate with their world, even within the Italian classroom. When students participate in this type of learning, they cannot disregard historical and current injustices. It is easier and less provocative to interact with communities as tourists (Byram, 1997) profiting from advantaged places without recognizing truths of class, race, coercion, and control. Learners are unable to participate successfully within 
the societies about which they study without also understanding the societal, historic, commercial, and political contexts in which they exist. In the present political climate in which our language classrooms are positioned, learners clearly need to communicate not only in the most operative way probable, but also in ways that facilitate problem solving. Educators cannot teach learners to participate in intercultural communication without also conveying cognizance of disparities that exist within and between studied communities. Instructors must free themselves of the one-dimensional ideal of a speech community so that students can acquire a multidimensional assessment of history and effectually analyze it. Teaching history in the target language can be challenging and result in shallow, remote pictures from history. Instructors often present Italian language and culture as a superficial, homogenous entity. Thematic units devoted to simplified perspectives praising the worlds of fashion and sports, for example, all too often lack a critical perspective with which to consider Italy's culture and history and thus opportunity to question hegemonic notions embodied within them. These texts should have the objective to arouse the learners' critical cultural awareness by examining practices, products, and perspectives of the culture being studied and one's own through a critically conscious lens.

False resources created for the language learner prioritize language over culture (Moeller \& Fatlin Osborn, 2014). If language learning alone is the only objective of instruction, such constructed texts serve a clear purpose. However, if language learning is about arriving at other cultures through language and increasing views, then more critical texts and materials afford occasions for critical language and culture learning (Randolph \& Johnson, 2017). Instructors convey an artificial framework interpretation into the classroom at the peril of disseminating stereotypes that do not improve students' cultural capabilities (Garrett-Rucks, 2016). When educators fail to consider such a critical perspective, students are left with prearranged interpretations of culture not developed through a critical method. Instructors need to take a critical approach in the language classroom and must not sustain outdated texts and pedagogical practices. Language learners must engage in critical analysis to learn different cultures in order to perceive the world themselves.

\section{B. Language Learning and Teaching}

A determination whether and under what circumstances critical pedagogy can fit Italian language pedagogy is required. Learners can encounter syntactic structures or words they do not comprehend. Whether they miscue the significance of parts of the discourse depends on their level of capability. The effort to integrate critical pedagogy into communicative language teaching means reconsidering the methodology of accommodating occasions for critical analysis in the linguistic curriculum in addition to the discourses in and for which the L2 is used (Briedbach, Medina \& Mihan, 2014). It proposes reassessing the relation of the learners' language and the L 2 being acquired, in addition to the functions both have for different curriculum elements. Critical pedagogical L2 teaching should be grounded on a two-sided curriculum made up of the traditional language curriculum as well as a curriculum of discourse addressing critical analysis matters. In this case, the L2 can become the communication standard in relation to the learners' growing ability. The critical discrepancy between a language and a discourse curriculum accommodates understanding that learners at all levels should be permitted and directed to scrutinize discourse related to the L2 critically. Communicative language teaching should emphasize task provision for the functional language. Distinguishing between first- and second-order tasks (Breidbach, 2011) allows differentiation between nonreflexive tasks in a traditional language curriculum and instances for a more reflexive structure open to negotiation of content, aim, and structure in learning contexts.

Foreign language materials for critical pedagogy are expected to foster social and language-skill development (Rashidi \& Safari, 2011). Learners acquire new means to question the status quo and engage in transformative actions to eradicate inequalities while they master the target language (Reagan \& Osborn, 2002). A critical curriculum formulates students who read the world (Freire \& Macedo, 1987). In the same vein, L2 materials should aid students to transcend the written word to arrive at an understanding of the world's authenticities and act to alter the world. Language-learning skills are not effective alone, but only in relation to transformative action (Rashidi \& Safari, 2011).

Foreign language materials typically have a set of prespecified goals and outcomes. In a critical pedagogy framework, such strong and exact outcomes are not recognized. Foreign language materials creators can design activities to allow learners to attain strong results. The exercises should let instructors and learners contribute in dialogical development while they practice language skills (Rashidi \& Safari, 2011). Learners and instructors can discover cultural morals, traditions, and principles in the language being studied as well the student's primary language to examine the parallels and variances among societies and work to alter basic inequalities (Crawford, 1978).

The issues and topics encompassed in L2 resources should generate rich dialog and examination. Overall, propagative themes proposed by learners define the organization of the content of the L2 materials (Rashidi \& Safari, 2011). Such themes could revolve around matters of American culture, target language culture, or the relationship between the two. Additionally, some themes can extend to critique other multiplicative themes. In this case, the instructor can turn the suggested topics into the L2 being studied, recognize the vocabulary and constructions the learners are required to study, and offer resources for language learning. Crawford (1978) pointed out that linguistic content may also produce some cultural points for students to explore the differences between first and target language structures and examine their fundamental values.

The means of educating is by involving students in a series of reflection and action by implementing dialogical problem-posing exercises. Acting to change the world to improve society satisfies the calling relative to critical pedagogy. To this end, Crawford (1978) posited that individuals should act reflectively; thus, education's task is to aid 
people to fulfill their human inclination by including them in the cycle of reflection and action. That is praxis. By requiring learners to partake in dialogical problem-posing practices, they initially decide on the content of discussion and then relate the issue or problem to their own lives (Rashidi \& Safari, 2011). After personalizing the problem, the instructor poses questions aimed at critically challenging learners and guiding them towards conversation on the socioeconomic, political, or cultural reasons of the problem as a form of decodification. Crawford (1978) claimed traditional class discussions are antidialogical. Predefined ideas chosen by the instructor may not correspond to learners' experiences and perceptions, but are what students are supposed to accept. In contrast, in a critical language classroom, discussion is for creation, not of an idea. Students combine their experiences to express the topic for themselves and articulate freely what they think about it (Rashidi \& Safari, 2011).

Continuing learner assessment is a central component of any critical language-learning program (Degener, 2011). Activities must develop learner growth, maturity, and empowerment. Thus, assessment turns into a manifestation of a learner's conception and application of acquisition (Reagan \& Osborn, 2002). An exercise may entail text or images conveying an unknown issue people generally regard as a social norm and not a problem, and then require learners to share their perceptions (Rashidi \& Safari, 2011). Foreign language materials can provide activities to assess linguistic aptitude. Crawford (1978) considered that such activities can reveal to learners the degree and value of their cognitive growth and increasing ability to use the L2. Such exercises also can determine the integrity of the critical language pedagogy at hand. Language-learning materials should also move away from assigning usual homework projects and instead assign tasks for learners to gather, choose, or generate matters and pedagogical resources. Altering the learner's part in critical language-learning materials from an inactive container to a creative student also alters the prospects positioned on the learner. Instead of blindly receiving information to remember and later regurgitate, the student uses the language knowledge and skills to confront the topic at hand. In this emancipated role, learners have freedom to decide topics, themes, and linguistic content. In this way, they dynamically partake in cultural codification and decodification processes (Rashidi \& Safari, 2011).

Crawford (1978) upheld that current L2 learning materials separate the learner from concern and the prospect to be imaginative and dynamic in the language process. According to Crookes (2009), increased availability and assortment of sample materials that aid instructors in acquainting themselves with critical theories in relation to language learning in critical L2 pedagogy classes could enhance the pragmatism of critical pedagogy. For example, an outline of key principles considered crucial in creating materials could support instructors (Rashidi \& Safari, 2011), but there exists a dearth of research on materials development in critical pedagogy (Crookes, 2009). This study attempted to create a prototype for designing materials in agreement with critical pedagogy philosophies.

Foreign language materials should advance learners' communicative skills while promoting learners' critical consciousness (Rashidi \& Safari, 2011). Most language-learning materials are comprised of exercises with the goal of refining L2 communicative skills regardless of social problems and contexts. They thereby reflect the traditional "banking method" of education (Reagan, 2006). Materials should develop learners' language skills as well as cognizance of the social structures. In a critical L2 pedagogy, materials aim to achieve this dual objective (Crookes \& Lehner, 1998). Therefore, the major task of L2 learning materials should be to enable learners to read their world and not simply the word (Freire \& Macedo, 1987). Foreign language can become a way to discover sociopolitical matters and cultural ethics (Reagan \& Osborn, 2002). Learners' language skills could be a way to critically discover and transform situations in their own and in the target language society (Degener, 2001).

\section{Transformative Learning}

Because critical pedagogy entails learners viewing the world in different ways, shifting their own understandings, and taking the interlocutor's standpoint (Byram, 1997), for learners of Italian, learning becomes transformative in nature. Transformative learning (Mezirow, 1991) defines the process of re-examining formerly held views and assumptions and learning to understand practices from a new standpoint. Advocates of critical pedagogy in the language classroom make a strong case for why transformative learning is essential: Learners must cultivate an idea of identity in which they obtain consciousness about their own values before getting to know another culture (Randolph \& Johnson, 2016). Learners must explore how they developed their own awareness of society. By contesting their own notions of truth, they become better equipped to discover another culture (Moeller \& Fatlin Osborn, 2014). Mezirow (1991) discussed the perspective through which one sees the world, the assemblage of one's views, expectations, understandings, and cultural norms as a meaning perspective. Most people make sense of their understandings by viewing society from a static lens. The information a learner obtains is filtered through the meaning perspective. This lens comprises essentials such as social norms, cultural codes, and common sense. These elements permit people to live within the parameters of their native culture and readily reject input that does not align with their system. A standard component of language acquisition comprises becoming taught the codes and conventions of one's native culture. Intercultural connection places contrarily mixed individuals in communication and many times leads to conflict (Randolph \& Johnson, 2016). Perspective transformation is the process of becoming critically conscious of how and why our conventions have come to pressure the way we observe society, imagining an all-encompassing outlook, and permitting learners to act based on this new awareness (Mezirow, 1991).

Constructing relations with people who are different entails considered risk-taking for the learner and a desire to confront issues, contradictions, and trials of cultural variances (Sosulski, 2013). Having this capacity requires learners' 
personal growth. Thus, transformative language learning is about not solely language, but also enlightening ourselves and the ways we relate with others (Randolph \& Johnson, 2016). Language acquisition is one of the most human actions we can undertake. Research in transformative language learning (Shrum \& Glisan, 2010) helps educators focus on the humanity beneath the pedagogical practices and support learners to see the world in different ways.

\section{Ideas for Novice and Intermediate Learners}

A major issue with novice Italian language learners is that they have not yet established the required language ability to participate in critical thought in the Italian language. Educators must wisely consider how to utilize critical language-learning goals to foster growth of the learners' linguistic capabilities. They should choose critical pedagogy themes that connect to language topics in beginner courses, judiciously choose materials with supplementary level-suitable knowledge exercises, and permit students to deliberate in their first language in a way that does not impede their progress in the Italian language (Randolph \& Johnson, 2016). At the beginning of the course, an instructor could present, for example, a critical theme by integrating readings, activities, and discussions connected to the grammar and or cultural topic being reviewed. For language transcripts too challenging for beginners to comprehend, instructors could change what learners have to do with the text rather than adapting the text (Shrum \& Glisan, 2010). Learners can even work on follow-up work constructed on the resources studied and themes discussed during class. Depending on the arrangement and level of critical engagement necessary, homework can be done in the target language or English, which can be reflective, action based, or a combination of the two. The instructor could enable a follow-up reflective discussion in English about hegemony and stereotypes, for example. Regardless of the activity, through cautious preparation and solid, thematic curricular strategy, learners can participate in evocative critical work early in the course (Randolph \& Johnson, 2016). Critical themes support the students' Italian language development while simultaneously presenting occasions for them to use English to participate critically. Although instructors may want to keep their students speaking Italian most of the time, the tactical use of English can help integrate critical pedagogies without sacrificing language proficiency objectives (Johnson \& Randolph, 2015). Critical pedagogy is not averse to using a first language in the L2 classroom because it may help with meaning negotiation (Larson, 2014).

Turning to the intermediate level of Italian, learners begin inventive thought using whole sentences. Although requiring less scaffolding than beginners, their language skills are still inadequate to partake in subtle discourse about critical matters. Thus, instructors could adjust the strategies mentioned previously, as well as the deliberate use of English, to intermediate learners to reach critical pedagogy objectives (Randolph \& Johnson, 2017). As intermediate learners acquire growing ability in the Italian language, instructors can substitute communicative exercises with activities that pertain more to critical communicative frameworks. For example, when learners study how to describe past actions, they can participate in debates, discussions, and skits about life stories that formed their cultural, ethnic, sexual, and gender self-identities. The goal is to insert critical matters in a way that encourages language ability objectives and other fundamentals from the world language curriculum while simultaneously permitting learners space to partake in transformative learning.

Intermingling with Italian speakers in the proper setting can be a transformative experience. Intermingling with target language communities abroad can be problematic (Byram, 1997) because learners often believe they are traveling to another country to enlighten others. Instructors contribute to this process by asking learners to complete projects that are invasive or emphasize stereotypes. Language instructors must instead challenge learners to uphold a critical outlook and be open to developing their own opinions (Randolph \& Johnson, 2017). Instructors can propose exercises such as creating journals, blogs, and discussion boards that permit learners to be involved in self-reflection rather than objectification and analysis of others (Arends, 2014).

Another way to approach critical pedagogy is through codes. In a Freirian context, codes are tangible physical expressions that signify all facets of a subject around an issue (Freire, 1970). They can take many forms, including pictures, illustrations, collages, stories, written dialogues, films, or songs and encourage critical thinking and discussion. When using a code, learners should designate the problem, comprehend how it relates to them, find causes, simplify it to others, and propose alternatives or resolutions (Wallerstein, 1983). Technology facilitates the use of codes in the form of news articles, YouTube videos, cartoons, advertisements, short stories, and blogs (Larson, 2014). A prearranged study program may limit many instructors, but codes could be applied sporadically to look critically at some issues. Regardless, these ideas attempt to implement Freire's concept that we cannot deposit our ideas into others or think for or without others (Au \& Apple, 2007). Instead, education is the practice of freedom, not of domination, and instructors must encourage the process of producing and acting upon ideas-not consuming those of others (Álvarez et al., 2012).

When choosing texts, it is important to pay attention to illustrations and characters (Ooiwa-Yoshizawa, 2012). Characters should represent nonnative Italian speakers using Italian and a variety of races, genders, disabilities, ages, and families, such as divorced parents and gay couples. Instead, by including a wide array of individuals, the texts can deter perpetuating social norms that tend to marginalize people who do not fit traditional expectations (Goodmacher, 2008). Instructors can also develop course materials rather than using a course book for advanced discussions (Sandy \& Kelly, 2009). Learners can select social issues relevant to them, read articles on these themes, and discuss societal power relations. With correct scaffolding, learners can raise an issue, critically analyze it, discuss how that power is reflected and reproduced in their own society, position, and problems, and brainstorm actions they can take.

Instructors should question whether they are representing a discriminatory society and perpetuating the status quo 
when providing supplemental materials, visual aids, and example sentences (Ooiwa-Yoshizawa, 2012). Subtle changes towards this end may include using "she" as an engineer and "he" as a nurse in example sentences. Instructors should switch stereotypical gender roles and vary nontraditional gender orientations when possible. The objective is not to occupy classroom time with the discussion of these social issues per se, but to purposely include groups of people that would otherwise be disregarded (Sandy \& Kelly, 2009).

\section{THEMATIC CONSIDERATIONS FOR THE ITALIAN LANGUAGE CLASSROOM}

Too often, the Italian language classroom concentrates on themes of stereotypical norms, such as coffee house life, town square, family life, cuisine, and soccer matches. Although all are important aspects of Italian culture, they frequently are presented in two-dimensional, positivist, and decontextualized formats void of potential for critical discussion or for learners to reflect critically on their own culture. The topics focus solely on language acquisition through culture, without transformative learning prospects. Learners risk perpetuating not only common stereotypes of Italian speakers and italophone cultures, but also potential cultural hegemonic ideologies. This leaves no space to question existing power structures or discuss marginalized groups leaners find relevant to their own lives and may use as a springboard for emancipatory action. Instead, thematic topics may be inserted into the Italian language-learning classroom as catalysts for not only language learning, but also the critical thinking currently absent in Italian pedagogical practices.

Displaying examples of important pieces from Italy's contemporary Arte Povera movement could provide rich class discussion, as well as an exciting opportunity for learners to not only amplify vocabulary related to art, colors, materials, and shapes, but also stir within them commentary on the dramatic ways these artists attacked the values of established institutions of government, industry, and culture. Such is the case with Michalengelo Pistoletto's iconic Venus of the Rags. Arte Povera usually incorporates organic and industrial materials in ways that reveal conflicts between the natural and man-made (Lista, 2006) and facilitates analyzing incorporation of the environment and its accompanying vocabulary. Such in-class analyses through student discussions around these artwork provide not only a unique vehicle towards acquiring Italian through a critical lens, but also a starting point to contest issues addressed in the Arte Povera moment and reflect on American consumer culture.

The Slow Food Movement, founded in Italy, is a grassroots organization that strives to preserve traditional and regional cuisine. It encourages farming of plants, seeds, and livestock characteristic of local ecosystems and promotes sustainable foods and small businesses to combat negative aspects of globalization on agricultural products (van Bommel \& Spicer, 2011). Internet clips and short readings on this subject vary in language proficiency level and are offered in English. They can foster vocabulary-building in topics ranging from food to economy and environment and discussions on ecology, fast food, industrial food production, nutrition, ecoregions, ethical consumerism, and organic farming. Optimally, opportunities for the class to visit a small farm or have local farmers or small business people who support slow food practices come to the classroom would promote rich experiences for the learners. These consequentially promote further discussion, outside research, or assignments in where learners apply Slow Movement concepts to North American contexts. For example, they may confront issues of food deserts, genetically modified foods, pesticide use, organic food culture, ethical eating, "McDonaldization," and the importance of composting, cocacolinization, and cultural imperialism. The instructor can modify all these example thematic units to fit students' specific needs, interests, and levels.

The trial and conviction of Sacco and Vanzetti is another potential thematic unit upon which Italian language skills can be strengthened and, more importantly, critical discussion borne on a vast range of subjects. The instructor can develop and assign short readings in English or at the students' Italian level for reading in or out of class. Depending on the students' linguistic competence, grammar in context may vary, but amplification related to trials, laws, human and workers' rights, immigration, and racism can be covered. On a deeper level, discussion around labor unions in the United States and Italy, as well as the U.S. judicial system, can reflect the unjust treatment of immigrants (Joughin \& Morgan, 2015) - in this case, Italians in America's past. Students can then be asked if similarities exist between the blatant discrimination demonstrated in the Sacco and Vanzetti trial and the current landscape in the United States, particularly among Latino and Muslim immigrants. Discussion may also be on anarchism or the death penalty. In addition, students may theorize about why the Sacco and Vanzetti case - although having received strong support from workers' movements internationally, American folk singers, and even Gutzon Borglum, sculptor of Mount Rushmore (who created a sculpture commemorating the two Italians) - currently remains hidden from the public, largely undiscussed in American history. Discussions of this nature could also tie to an explanation and reflection on the importance of May Day or International Worker's Day in Italy. In Italy, it started initially as an attempt to celebrate workers' achievements in their struggle for their rights and for better social and economic conditions. It was abolished under the Fascist Regime and immediately restored after the Second World War. May Day is now an important celebration in Italy and a national holiday, regardless of on which weekday it falls. This could be another potential juxtaposition in either Italian or English of Italy's Festa dei lavoratori and America's Labor Day, with the instructor comparing both celebrations with photos (e.g., PowerPoint), short readings in English and Italian, and simplified readings in Italian, depending on the learners' level.

Film showings and subsequent class discussions offer a treasure trove of opportunities to better foster critical thought 
amongst learners of Italian while they study vocabulary, grammar, culture, and cinematic history. Films from the neorealist period demonstrate a watershed moment in world cinematic history regarding technique. Also, their subject matter exposes the shallowness of modern capitalist society and exploitation of working-class people. Their unique focus on the real-life problems of common people, poverty, crime, and social injustice (Bondanella, 2012) can steer learners to reflect on modern mainstream films and their roles in society as entertaining as opposed to revelatory or emancipatory. Films ranging from Bicycle Thieves to Umberto D are obvious choices because they delineate the extent of the neorealist movement. The instructor may also offer vocabulary related to cinema production, technique, poverty, class issues, and beyond, and assign reflection journals in either English or Italian, depending on the level.

Similarly, films from Italy's commedia all'italiana or Italian style comedy period from the late 1950s to the early 1970s often contained social criticism. Films of this era provide an accurate mirror of changing Italian customs and values. They aided in forcing the average Italian into a greater awareness of conflicting values by attacking age-old prejudices and questioning the inept rule of governing elites and institutions (Bondanella, 2012). They often embodied a dark, grotesque vision of contemporary Italian society; laughter in these works was bittersweet. Similar to the neorealist activities, film showings from the commedia all'italiana era can spark critical discussion and readings in Italian or English on a myriad of cultural progressions and changes within Italian culture, such as the once-illegal divorce from the famous Divorce Italian Style. They also can be compared to those of American culture. This could segue into themes of more contemporary issues in Italy and the United States addressed in many older and modern films, such as those of Paolo Sorrentino and The Great Beauty, a commentary on spiritual and moral emptiness in a modern consumerist, celebrity culture.

Critical themes often ignored in traditional Italian classes abound as they relate to Italian acquisition and culture and reflect the learner's own culture. Articles, clips, and readings in either English or an appropriate Italian level can cover a plethora of subjects, including civil unions in Italy starting in 2016 and gay marriage in the United States and other civil rights; photos and articles concerning Italy's Triangle of Death and vocabulary and readings concerning environmental issues and their ecological relationship to health concerns and organized crime and big business collaboration; clips and readings on fascism then and now in Italy and the United States, including growing extremists groups and causes of their rise; discussions on the current economic crisis in Italy, austerity measures, brain drain, and bank bailouts linked to more advanced readings with economy-related vocabulary lists; Italian advertisements for products in Italy and the United States and their power, embeddedness, and allusiveness in our society can introduce learners to the concept of Gramsci's cultural hegemony (Gramsci et al., 1971) as a critique of consumerist culture, so students can reflect on their own experiences when questioning the status quo; showing the documentary-like film Fire at Sea to initiate a powerful discussion on the European migrant crisis and a juxtaposition to migrants entering the United States and reflecting on its causes, in addition to resistance fueled by nationalism and racism; the theme of racism in Italy can also be discussed in light of racist remarks against Sicilian-born soccer star of Ghanaian parents Mario Balotelli, the plight of Africans in a previously overwhelmingly monocultural society, and accomplishments and achievements of Cécile Kyenge, Italy's first black cabinet minister. The instructor can use these example thematic units with discretion and adapt to learners' pedagogic cultural and linguistic needs to better foster critical thinking through Italian learning as a tool for empowerment, resistance, conscientization, dialogism, and to prevent cultural reproduction, marginalization, and devaluation.

\section{Conclusion}

Some inquiries must be examined for imminent study and research. The first deals with the effects of instruction for critical pedagogy in Italian language-learning classrooms. The complete and utter dearth of critical perspective with regards to Italian language pedagogy leaves a great deal to explore in regards to practices, techniques, and evaluation. Such an examination would comprise topics and issues covered herein, choice of writings, responsibilities given to learners, and practice of classroom language. Regarding suitable texts, investigation can be done with not only established research, but also more recent texts with a higher likelihood of stressing and observing particular social matters. Another issue concerns possible procedures for instructing critical thinking. Configuring such strategies begs the question whether the concept of critical pedagogy is truly compatible with the limiting strategies. The effect of the critical pedagogies notion on orders between instructors and learners, evaluator and evaluated, also needs consideration for more profound investigation (Breidbach et al, 2014). This would consist of research into instructor education at the university level and how future language instructors can acquire critical pedagogy technique. Postulations that the growth of critical pedagogy would simply shadow language learning are dubious. Instead, focused pedagogies for developing critical thinking are essential, if founded in insightful theory and strong empirical work. The many published case studies in the field of critical pedagogy specify that waiting for critical pedagogy to develop accidentally is unrealistic for language educators.

Although the phrase "critical pedagogy" is seldom mentioned in the field of Italian language learning, some language instructors encourage and exercise critical themes such as global issues and critical thinking (Ooiwa-Yoshizawa, 2012). As L2 critical pedagogy theory becomes more commonly known by educators, this powerful theory could bond those instructors as critical teachers. When instructors share their thoughts, resources, and curricula as examples of practical L2 critical pedagogy, the influence of a receptive and knowledgeable group can aid other instructors. Societal 
improvement should be an unbiased objective of every Italian language classroom. Instructors represent transformation, and transformative pedagogy is radical in nature (ELT News, 2011). Critical pedagogy can apply in classrooms at countless levels and contexts. When learners perceive their social power, encounter a shift of power, and acquire sensitivity and inclusion of diversity, an Italian language classroom can be a learning community that leads to empowerment. Italian language critical pedagogy is crucial to further the community and broader society. This literature review proposes that the present challenge in the Italian language classroom is to recognize methods to improve not only learners' Italian language proficiency, but also their cultural awareness. One way to achieve this is by applying a critical pedagogical approach to the language classroom. In the critical classroom, learners question class content, and instructors develop resources to approach Italian culture in alternative ways. The educational system often has been defined as a system in which explicit cultural values are reproduced by developing specific outlooks in learners and instructors who then creates specific practices (Bourdieu \& Passerson, 1998). Those practices empower them to question conformist ways of seeing the world and enhance learning (Moreno-Lopez, 2004). By applying critical pedagogy, the Italian language classroom has potential to become a space in which learners attain language proficiency as well as develop critical awareness, a growing imperative in the ever-increasing neoliberal influenced culture of education.

\section{REFERENCES}

[1] Adorno, T. W. (2007). Prisms. Cambridge, MA: MIT Press.

[2] Aliakbari, M. \& E. Faraji. (2011). Basic principles of critical pedagogy. 2nd International Conference on Humanities, Historical and Social Sciences IPEDR 17, 78-85.

[3] Álvarez, Z., M. Calvete \& M. C. Sarasa. (2012). Integrating critical pedagogy theory and practice: Classroom experiences in Argentinean EFL teacher education. Journal for Educators, Teachers and Trainers 3, 60-71.

[4] Araya Araya, K. (2007). Teaching materials: A critical position about the role they play in the language classroom. Actualidades Investigativas en Educación 7.3, 1-16.

[5] Arends, J. (2014, January 21). "Just collecting data for the white guys": Community impacts of service-learning in Africa. from http://tinyurl.com/htqjky7 (accessed 12/11/2017).

[6] Au, W. W. \& M. Apple. (2007). Reviewing policy. Freire, critical education, and the environmental crisis. Educational Policy 21.3, 457-470. doi:10.1177/0895904806289265.

[7] Bondanella, P. E. (2012). Italian cinema. New York: Oxford University Press.

[8] Bourdieu, P. \& J. C. Passerson. (1998). Reproduction in education, society and culture. Thousand Oaks, CA: Sage.

[9] Breidbach, S. (2011). Teaching for "strong voices": Reconstructing the reflexive dimension in communicative language teaching. In S. Breidbach, D. Elsner \& A. Young (eds.), Language awareness in teacher education. Frankfurt: Peter Lang, 97-113.

[10] Breidbach, S., J. Medina \& A. Mihan. (2014). Critical literacies, multiliteracies and foreign language education. Fremdspachen Lehren und Lernen 43.2, 91-106.

[11] Byram, M. (1997). Teaching and assessing intercultural communicative competence. Philadelphia, PA: Multilingual Matters.

[12] Canagarajah, S. (2005). Critical pedagogy in L2 learning and teaching. In E. Hinkel (ed.), Handbook of research in second language teaching and learning. Mahwah, NJ: Lawrence Erlbaum Associates, 931-949.

[13] Crawford, L. M. (1978). Paulo Freire's philosophy: Cerivation of curricular principles and their application to second language curriculum design. Ph.D. dissertation, University of Minnesota.

[14] Crookes, G. (2009). The practicality and relevance of second language critical pedagogy. Language Teaching 43.3, 333-348. doi:10.1017/S0261444809990292.

[15] Crookes, G. (2012). Critical pedagogy in language teaching. In L. Ortega (ed.), The encyclopedia of applied linguistics. Oxford: Wiley/Blackwell.

[16] Crookes, G. \& A. Lehner (1998). Aspects of process in an ESL critical pedagogy teacher education course. TESOL Quarterly 32.2, 319-328. doi:10.2307/3587586.

[17] Dallmayr, W. R. \& T. McCarthy. (1977). Understanding and social inquiry. Notre Dame, IN: University of Notre Dame Press.

[18] Degener, S. C. (2001). Making sense of critical pedagogy in adult literacy education. Annual Review of Adult Learning and Literacy 2, 26-62.

[19] Dewey, J. (2017). Democracy and education. Lanham, MD: Dancing Unicorn Books.

[20] ELT News. (2011). Interview with Chuck Sandy. http://www.eltnews.com/features/interviews/ 2003/04/interview_with_chuck_ sandy. html (accessed 17/10/2017).

[21] Farias, M. (2005). Critical language awareness in foreign language learning. Literatura y Lingüística 16, $211-222$. doi:10.4067/S0716-58112005000100012.

[22] Freire, P. (1970). Pedagogy of the oppressed. New York: Continuum.

[23] Freire, P. \& D. Macedo. (1987). Literacy: Reading the word and the world. London: Routledge.

[24] Garrett-Rucks, P. (2016). Intercultural competence in instructed language learning: Bridging theory and practice. Charlotte, NC: Information Age.

[25] Gibson-Graham, J. K. (2006). A post-capitalist politics. Minneapolis: University of Minnesota Press.

[26] Giroux, H. A. (1979). Schooling and the culture of positivism. Educational Theory 29.4, $263-284$. doi:10.1111/j.1741-5446.1979.tb00859.x.

[27] Giroux, H. A. (1988). Schooling and the struggle for public life. Minneapolis: University of Minnesota Press.

[28] Giroux, H. (2008). Pedagogy and the politics of hope: Theory, culture, and schooling. New York: Westview Press.

[29] Goodmacher, G. (2008). Stimulating conversation. Fukuoka: Intercom Press.

[30] Gramsci, A., Q. Hoare \& G. Nowell-Smith. (1971). Selections from the prison notebooks of Antonio Gramsci. New York: 
International Publishers.

[31] Greene, M. (1989). Landscapes of learning. New York: Teachers College Press.

[32] Habermas, J. (2014). Toward a rational society. New York: John Wiley \& Sons.

[33] Held, D. (2006). Introduction to critical theory: Horkheimer to Habermas. Berkeley: University of California Press.

[34] Husserl, E. \& Q. Lauer. (1994). Phenomenology and the crisis of philosophy. New York: Harper \& Row.

[35] Johnson, S. M. \& L. J. Randolph, Jr. (2015). Critical pedagogy for intercultural communicative competence: Getting started. Language Educator 10.3, 36-39.

[36] Joughin, L. \& E. M. Morgan. (2015). The legacy of Sacco and Vanzetti. Princeton, NJ: Princeton University Press.

[37] Keesing-Styles, L. (2003). The relationship between critical pedagogy and assessment in teacher education. Radical Pedagogy $5.1,1-20$.

[38] Kennedy, W. (1990). Integrating personal and social ideologies. In J. Mezirow (ed.), Fostering critical reflection in adulthood. San Francisco: Jossey-Bass, 99-115.

[39] Kincheloe, J. L. \& P. L. McLaren. (1998). Rethinking critical theory and qualitative research. In N. K. Denzin \& S. Lincoln (eds.), The landscape of qualitative research: Theories and issues. Thousand Oaks, CA: Sage, 403-456.

[40] Larson, K. R. (2014). Critical pedagogy(ies) for ELT in Indonesia. TEFLIN Journal 25.1, 122-138. doi:10.15639/ teflinjournal.v25i1/122-138.

[41] Lista, G. (2006). Arte Povera. Milan: 5Continents.

[42] Mezirow, J. (1991). Transformative dimensions of adult learning. San Francisco: Jossey-Bass.

[43] Moeller, A. \& S. R. Fatlin Osborn. (2014). A pragmatist perspective on building intercultural communicative competency: From theory to classroom practice. Foreign Language Annals 47.4, 669-683. doi:10.1111/flan.12115

[44] Moore, B. N. \& R. Parker. (2016). Critical thinking. New York: McGraw-Hill Education.

[45] Moreno-Lopez, I. (2004). Critical pedagogy in the Spanish language classroom: A liberatory process. Taboo: Journal of Culture and Education 8.1, 77-84.

[46] Nietzsche, F. W. \& A. Collin (trans.) (2015). The use and abuse of history. Mansfield Centre, CT: Martino Publishing.

[47] Norton, B. \& K. Toohey. (2004). Critical pedagogies and language learning: An introduction. In B. Norton \& K. Toohey (eds.), Critical pedagogies and language learning. Cambridge: Cambridge University Press, pp.1-17.

[48] Ooiwa-Yoshizawa, A. (2012). Implications of EFL critical pedagogy: Theory, practice, and possibilities. Keiwa Bulletin 21, 21-30.

[49] Pennycook, A. (1990). Critical pedagogy and second language education. System 18.3, 303-314. doi:10.1016/0346-251X(90)90003-N.

[50] Randolph, L. J., Jr. \& S. M. Johnson. (2016). Bringing culture instruction and social justice together in the language classroom [Video webinar]. American Council on the Teaching of Foreign Languages. https://www.actfl.org/ membership/special-interest-groups-sigs/teaching-and-learning-culture (accessed 10/10/2017).

[51] Randolph, L. J., Jr. \& S. M. Johnson. (2017). Social justice in the language classroom: A call to action. From http://www.scolt.org/images/PDFs/dimension/2017/1_Social\%20Justice_Randolph_2.pdf (accessed 10/10/2017).

[52] Rashidi, N. \& F. Safari (2011). A model for EFL materials development within the framework of critical pedagogy (CP). English Language Teaching 4.2, 250-259. doi:10.5539/elt.v4n2p250.

[53] Reagan, T. (2006). The explanatory power of critical language studies: Linguistics with an attitude. Critical Inquiry in Language Studies 3.1, 1-22. doi:10.1207/s15427595cils0301_1.

[54] Reagan, T. \& T. Osborn. (2002). The foreign language educator in society: Toward a critical pedagogy. Mahwah, NJ: Lawrence Erlbaum Associates.

[55] Richards, J. C. (2010). Series editor's preface. In N. Harwood (ed.), English language teaching materials: Theory and practice. Cambridge: Cambridge University Press, ix-xi.

[56] Sadeghi, S. (2008). Critical pedagogy in an EFL teaching context: An ignis fatuus or an alternative approach? Journal for Critical Education Policy Studies 6.1, 276-295.

[57] Sandy, C. \& K. Kelly. (2009). ACTIVE skills for communication: Student book 1. Boston: Heinle, Cengage Learning.

[58] Shaull, R. (2007). Foreword. In P. Freire (ed.), Pedagogy of the oppressed. New York: Continuum, 29-34.

[59] Shrum, J. L. \& E. W. Glisan. (2010). Teacher's handbook: Contextualized language instruction. Boston: Heinle.

[60] Sosulski, M. (2013). From Broadway to Berlin: Transformative learning through German hip-hop. Die Unterrichtspraxis 46.1, 91-105. doi:10.1111/tger.10131.

[61] van Bommel, K. \& A. Spicer. (2011). Hail the snail: Hegemonic struggles in the Slow Food Movement. Organization Studies 32.12, 1717-1744. doi:10.1177/0170840611425722.

[62] Wallerstein, N. (1983). Language and culture in conflict: Problem-posing in the ESL classroom. Reading, PA: Addison-Wesley.

[63] Wellmer, A. \& J. Cumming (trans.) (1974). Critical theory of society. New York: Herder \& Herder.

Formato, Giuseppe. PhD (2018) in Educational Studies and Adult Learning and Development from Lesley University, Cambridge, Massachusetts, USA. MA (2013) in Applied Linguistics with a specialization in Foreign Language Pedagogy and BA (2011) in Italian Studies from the University of Massachusetts Boston. He is currently an adjunct professor at Lesley University where he teaches courses in Italian, Portuguese, and Cinema; an invited guest lecturer to Emmanuel College and the University of Massachusetts; and a Camões Fellow at the Camões Institute in Boston. His research interests include language acquisition, critical pedagogy, and linguistic variation. 